\title{
The alternative sigma factor AlgT, but not alginate synthesis, promotes in planta multiplication of Pseudomonas syringae pv. glycinea
}

\author{
Correspondence \\ Matthias S. Ullrich \\ m.ullrich@jacobs-university.de
}

Received 2 September 2007

Revised 1 November 2007

Accepted 7 November 2007

\author{
Alexander Schenk, Helge Weingart and Matthias S. Ullrich \\ Jacobs University Bremen, School of Engineering and Sciences, Campus Ring 1, 28759 Bremen, \\ Germany
}

The phytopathogen Pseudomonas syringae pv. glycinea produces the exopolysaccharide (EPS) alginate, which is thought to function in epiphytic fitness and virulence. A key regulator for alginate biosynthesis in Pseudomonas aeruginosa and $P$. syringae is the alternative sigma factor AlgT $\left(\sigma^{22}\right)$. In this study, the contribution of alginate synthesis and AlgT to in planta epiphytic fitness and virulence of $P$. syringae was examined. Alginate biosynthesis mutants were generated for the $P$. syringae pv. glycinea strains PG4180 and PG4180.muc, representing a comprehensive set of alginate- and AlgT-positive or -negative derivatives. Analysis of in vitro and in planta phenotypes revealed that AlgT strongly promoted in planta growth, survival and symptom development, but decreased the ability to grow in vitro. In contrast, alginate biosynthesis had only marginal impact. Quantitative in vitro and in planta gene expression analyses for alginate biosynthesis and algT were carried out at two temperatures in AlgT-negative and -positive backgrounds. algT as well as algD gene expression was AlgT-dependent, plant-inducible and temperature-dependent, with higher expression at 18 compared to $28^{\circ} \mathrm{C}$; however, no temperature dependence was observed in vitro. Our data suggest that AlgT may act as a global regulator for virulence and in planta fitness traits of $P$. syringae independent of its role in EPS biosynthesis.

\section{INTRODUCTION}

Virulence of phytopathogenic bacteria is often associated with production of exopolysaccharides (EPSs), which mediate multiple functions, including water absorption, accumulation of minerals and nutrients, and protection from hydrophobic and toxic macromolecules (Denny, 1995). EPSs are carbohydrate polymers that are secreted by a wide variety of bacteria and form loosely associated extracellular slime or remain closely attached to cells in the form of capsules (Whitfield, 1988). Pseudomonas syringae pv. glycinea PG4180 infects soybean plants (Glycine max) and causes bacterial blight disease. The infection process involves epiphytic colonization of leaf surfaces, establishment of infection sites via entry into the plant apoplast, multiplication within host tissue and development of disease symptoms (Alfano \& Collmer, 1996; Hirano \& Upper, 2000). P. syringae and other plant-pathogenic bacteria may cause 'cold-weather' diseases and many genes studied with respect to temperature exhibit increased transcription at temperatures well below the respective growth optima (Ullrich et al., 2000). This includes virulence determinants such as those directing bacteriato-plant gene transfer, plant cell-wall-degrading enzymes,

Abbreviation: EPS, exopolysaccharide. phytotoxins, ice nucleation activity, the type III protein secretion machinery and EPS production (Smirnova et al., 2001). P. syringae pv. glycinea has been demonstrated to produce at least two EPSs: (i) the polyfructan levan and (ii) alginate, a copolymer of $O$-acetylated $\beta$ - $(1,4)$ linked $\mathrm{D}$ mannuronic acid and its C-5 epimer, L-guluronic acid (Gross \& Rudolph, 1987a; Hettwer et al., 1998; Osman et al., 1986).

$P$. syringae alginate production has been associated with increased epiphytic fitness, virulence, resistance to desiccation and toxic molecules, dissemination in planta (Rudolph et al., 1994; Yu et al., 1999) and the induction of water-soaked lesions on infected leaves (Fett \& Dunn, 1989). A positive correlation between virulence of $P$. syringae and the quantity of alginate produced in planta has been demonstrated (Gross \& Rudolph, 1987b; Osman et al., 1986). The biosynthetic route to alginate in $P$. syringae is similar to that established for $P$. aeruginosa, where alginate synthesis has been studied extensively and where it functions as a virulence factor in strains infecting the lungs of cystic fibrosis patients (Fett et al., 1992; Fialho et al., 1990; Peñaloza-Vázquez et al., 2004, 1997; Pier, 1998; $\mathrm{Yu}$ et al., 1999). Genes encoding enzymes of alginate biosynthesis in $P$. aeruginosa and $P$. syringae are organized in an operon $(\operatorname{alg} D-a \lg A)$, with the exception of $\operatorname{alg} C$ 
(Chitnis \& Ohman, 1993; Peñaloza-Vázquez et al., 2004, 1997; Zielinski et al., 1991). The first gene of the operon, algD, encodes a GDP-mannose dehydrogenase, whose activity is the kinetic control point and is indispensable for the alginate pathway (Tatnell et al., 1994). In $P$. syringae, algD is expressed during colonization of susceptible and resistant plant hosts (Keith et al., 2003). The alginate biosynthetic operon in $P$. aeruginosa is controlled by several two-component systems and by the alternative sigma factor, AlgT (Mathee et al., 2002). AlgT of $P$. aeruginosa acts as a global stress response sigma factor that activates transcription of the main heat-shock sigma factor $\mathrm{RpoH}$, as well as different virulence determinants or toxic factors (Firoved et al., 2002; Firoved \& Deretic, 2003; Schurr \& Deretic, 1997). AlgT in P. syringae $\left(\sigma^{22}\right)$ is encoded by the first gene of the algT-mucAB operon, which activates alginate biosynthesis by activating its own transcription and that of algD (Keith \& Bender, 1999; Schenk et al., 2006).

All wild-type $P$. aeruginosa strains have the genetic capacity to synthesize alginate, but normally produce only small amounts of this polymer (Anastassiou et al., 1987; Lam et al., 1980; Pier et al., 1986). Like P. aeruginosa, most phytopathogenic strains of $P$. syringae, including PG4180, are normally non-mucoid in vitro (Kidambi et al., 1995; Schenk et al., 2006). The loss of alginate production in $P$. syringae PG4180 is caused by a naturally occurring nonsense mutation in the alg $T$ gene, which by chance reverted in the alginate-producing derivative PG4180.muc (Schenk et al., 2006).

For $P$. syringae, the results of several previous studies have invited speculation on potential functions for alginate in planta. However, a comprehensive in planta study, which directly compares alginate and algT mutants, has not been reported thus far. In the present study, we investigated the contribution of the P. syringae EPS alginate and the sigma factor AlgT to in vitro and in planta growth, survival and virulence. Additionally, the impact of temperature on in vitro and in planta gene expression was analysed for algT and $\operatorname{alg} D$ in strains producing or lacking the AlgT sigma factor.

\section{METHODS}

Bacterial strains, plasmids and growth conditions. The bacterial strains and plasmids used in this study are listed in Table 1. Escherichia coli was maintained and grown at $37{ }^{\circ} \mathrm{C}$ on Luria-Bertani (LB) medium (Sambrook et al., 1989). P. syringae was routinely maintained at $28{ }^{\circ} \mathrm{C}$ on mannitol-glutamate (MG) medium (Keane et al., 1970). For liquid cultures at 18 or $28^{\circ} \mathrm{C}$, bacteria were grown in $200 \mathrm{ml}$ Hoitink-Sinden minimal medium (HSC) (Palmer \& Bender, 1993) in 11 Erlenmeyer flasks. Bacterial growth was continuously monitored by measuring $\mathrm{OD}_{600}$. Antibiotics were added to the media at the following concentrations $\left(\mu \mathrm{g} \mathrm{ml}^{-1}\right)$ : ampicillin, 50; kanamycin, 25; tetracycline, 25; gentamicin, 2 .

Table 1. Bacterial strains and plasmids used in this study

\begin{tabular}{|c|c|c|}
\hline Strain or plasmid & Relevant characteristics ${ }^{\star}$ & Reference or source \\
\hline \multicolumn{3}{|l|}{ Escherichia coli } \\
\hline $\mathrm{DH} 5 \alpha$ & 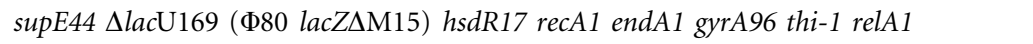 & Sambrook et al. (1989) \\
\hline SM10 & thi-1 thr leu tonA lacY supE recA:: RP4-2-Tc:: Mu; $\mathrm{Km}^{\mathrm{r}}$ & Hoang et al. (1998) \\
\hline \multicolumn{3}{|c|}{ Pseudomonas syringae pv. glycinea } \\
\hline PG4180.muc & Mucoid wild-type, $\operatorname{alg} T^{+}$ & Schenk et al. (2006) \\
\hline PG4180 & $\begin{array}{l}\text { Wild-type producing negligible amounts of alginate due to a point mutation } \\
\text { in } \operatorname{alg} T\end{array}$ & Schenk et al. (2006) \\
\hline PG4180.muc.alg & algD mutant derived from PG4180.muc; $\operatorname{alg} T^{+}$ & This study \\
\hline PG4180.alg & algD mutant derived from PG4180; algT & This study \\
\hline \multicolumn{3}{|l|}{ Plasmids } \\
\hline pGEM-T Easy & $A p^{r}$ & Promega \\
\hline pRK2013 & $\mathrm{Km}^{\mathrm{r}}$; helper plasmid & Figurski \& Helinski (1979) \\
\hline pEX18Tc & $\mathrm{Tc}^{\mathrm{r}}$, oriT ${ }^{+} \operatorname{sacB}^{+}$; gene replacement vector & Hoang et al. (1998) \\
\hline pPS858 & $\mathrm{Ap}^{\mathrm{r}} \mathrm{Gm}^{\mathrm{r}}$; FRT-cassette vector, containing $g f p$ & Hoang et al. (1998) \\
\hline pFLP2 & $\mathrm{Ap}^{\mathrm{r}}$, ori $T^{+} \mathrm{sacB}^{+}$; Flp recombinase-producing plasmid & Hoang et al. (1998) \\
\hline pGEM_algD_left\#3 & $\mathrm{Ap}^{\mathrm{r}}$; contains a 1386 bp BamHI-XbaI PCR fragment (located upstream of $\operatorname{algD}$ ) & This study \\
\hline pGEM_algD_right\#3 & $\mathrm{Ap}^{\mathrm{r}}$; contains a 2275 bp XbaI-BamHI PCR fragment (located downstream of algD) & This study \\
\hline pGEM_algD3_both & $\begin{array}{l}\text { Ap }^{\mathrm{r}} ; 2322 \text { bp XbaI-SacI fragment of pGEM_algD_right\#3 cloned into XbaI/SacI- } \\
\text { linearized pGEM_algD_left\#3 }\end{array}$ & This study \\
\hline pGEM_algD3_GmGFP & $\begin{array}{l}\mathrm{Ap}^{\mathrm{r}} \mathrm{Gm}^{\mathrm{r}} ; 1833 \text { bp SmaI FRT-cassette fragment of pPS858 cloned into } \\
\text { XbaI-linearized pGEM_algD3_both }\end{array}$ & This study \\
\hline pEX18Tc_algD3_GmGFP & $\begin{array}{l}\mathrm{Tc}^{\mathrm{r}} \mathrm{Gm}^{\mathrm{r}} ; 5950 \text { bp BamHI fragment of pGEM_algD3_GmGFP cloned into } \\
\text { BamHI-linearized pEX18Tc }\end{array}$ & This study \\
\hline
\end{tabular}

${ }^{\star}$ Ap, Ampicillin; Gm, gentamicin; Km, kanamycin; Sm, streptomycin; Sp, spectinomycin; Tc, tetracycline. 
Molecular genetic techniques. Small-scale isolation of plasmid DNA, restriction enzyme digests, agarose gel electrophoresis, purification of DNA fragments from agarose gels, electroporation, PCR, ligation of DNA fragments and other routine molecular methods were performed using standard protocols (Sambrook et al., 1989). Isolation of plasmid DNA from P. syringae was accomplished by the method of Kado \& Liu (1981). Genomic DNA from P. syringae was isolated as described by Ausubel et al. (1994). Sequencing was carried out commercially (MWG Biotech, Ebersberg, Germany).

Generation of algD mutants. $P$. syringae algD mutants were generated using the broad-host-range Flp-FRT recombination system (Hoang et al., 1998). Two fragments flanking the algD gene were PCRamplified from PG4180.muc genomic DNA using the oligonucleotide primer pairs algD_ol2, algD_il3 and algD_ir3, algD_or2 (Table 2). PCR products were cloned into vector pGEM-T Easy (Promega), yielding plasmids pGEM_algD_left\#3 (4871 bp) and pGEM_algD_right\#3 (5290 bp). A $2322 \mathrm{bp}$ XbaI-SacI fragment cut from pGEM_ algD_right\#3 was ligated into XbaI/SacI-digested pGEM_algD_left\#3, yielding the $7138 \mathrm{bp}$ plasmid pGEM_algD3_both. A $1833 \mathrm{bp}$ SmaI FRT-cassette fragment cut from pPS858 was ligated into XbaI-digested and blunt-ended pGEM_algD3_both, yielding the 8975 bp plasmid pGEM_algD3_GmGFP. A 5950 bp BamHI fragment cut from pGEM_algD3_GmGFP was ligated into BamHI-digested pEX18Tc yielding the final algD gene replacement plasmid pEX18Tc algD3_GmGFP $(12.3 \mathrm{~kb})$. This plasmid was mobilized into strains PG4180.muc and PG4180 by triparental matings with the helper plasmid pRK2013 (Figurski \& Helinski, 1979). Putative mutants were screened for homologous recombination events by checking their antibiotic resistance and GFP fluorescence. The FRT-cassette carrying $g f p$ and the gentamicin determinant was finally excised using the pFLP2 recombinase-encoding plasmid as described by Hoang et al. (1998). To confirm the altered genotypes, PCR amplification of algD using primers algD-cl and algD_cr (Table 2) was carried out, yielding a 903 bp fragment for the two mutants, as opposed to the presence of wild-type algD, forming a $1258 \mathrm{bp}$ PCR fragment in samples of PG4180 and PG4180.muc.

Isolation and quantification of alginate. Strains were grown on MG agar (three plates per strain) containing the appropriate antibiotics at $28{ }^{\circ} \mathrm{C}$ for $96 \mathrm{~h}$. Cells were washed from each plate and resuspended in $0.9 \% \mathrm{NaCl}$. Alginate isolation and quantification were performed as described by May \& Chakrabarty (1994), and alginic acid from seaweed (Macrocystis pyrifera; Sigma) was used as a standard. The experiment was repeated twice and mean values were obtained for the quantity of alginate produced per mg protein.

Determination of bacterial growth in planta. Growth of $P$. syringae in planta was evaluated on soybeans [Glycine max (L.) Merr. cv. Maple Arrow]. Soybean seedlings were grown in open shelves equipped with fluorescent lamps at $22-25{ }^{\circ} \mathrm{C}, 55 \%$ humidity, with a $16 \mathrm{~h}$ photoperiod $\left(350 \mu \mathrm{E} \mathrm{m}^{-2} \mathrm{~s}^{-1}\right)$. Two days before inoculation, plants were transferred to plant growth chambers (Conviron E/2) at 18 or $28{ }^{\circ} \mathrm{C}, 55 \%$ humidity, with a $16 \mathrm{~h}$ photoperiod $\left(350 \mu \mathrm{E} \mathrm{m}^{-2} \mathrm{~s}^{-1}\right)$. PG4180 strains were incubated for $48 \mathrm{~h}$ at $28{ }^{\circ} \mathrm{C}$ on MG agar. Cells were suspended in distilled water, adjusted to $1 \times 10^{7}$ c.f.u. $\mathrm{ml}^{-1}$ and applied to both surfaces of the leaves with an airbrush $(\sim 8$ p.s.i.) until the leaf surfaces were uniformly wet. Inoculated plants were transferred to shelves equipped with fluorescent lamps, and survival and growth of bacterial strains was monitored by removing random leaf samples at $0-28$ days postinoculation (three replicates per time point). Leaves were weighed separately and macerated in $10 \mathrm{ml}$ sterile PBS (g fresh wt $)^{-1}$ using a mortar and pestle. Bacterial counts [c.f.u. ( $g$ fresh wt $)^{-1}$ ] were determined by plating dilutions of leaf homogenates onto $\mathrm{MG}$ agar and counting fluorescent colonies after incubation at $28{ }^{\circ} \mathrm{C}$ for $96 \mathrm{~h}$.

\begin{abstract}
In vitro and in planta gene expression analysis by multiplexed fluorescent Northern hybridization. In vitro and in planta gene expression analysis was carried out according to our recently described method (Schenk et al., 2008). In brief, bacterial and plant total RNA was simultaneously isolated from leaf tissue infiltrated with P. syringae strains 3 days after inoculation. Total RNA was isolated by an acid-phenol extraction using an extraction buffer containing glycine, SDS, cetyltrimethylammonium bromide, high-molecularmass polyethylene glycol and $\beta$-mercaptoethanol steps followed by $\mathrm{LiCl}$ precipitation. Since total RNA samples isolated from infected leaf tissue represent a mixture in which the bacterial RNA portion is unknown, all expression data had to be normalized to a reference, such as the expression of $23 \mathrm{~S}$ rRNA. Therefore, DIG-labelled genespecific probes were multiplexed with an Oyster-645 fluorescencelabelled 23S RNA probe in a single Northern hybridization reaction. Hybridization probes of the following sizes internal to the structural genes were generated with respective primer pairs: for $\operatorname{alg} T, 536 \mathrm{nt}$ (algT_fwd, algT_revT7); algD, $641 \mathrm{nt}$ (algD_fwd, algD_revT7); 23S\#1, 146 nt (23S_fwd\#1, 23S_revT7\#1) (Table 2).
\end{abstract}

Table 2. Oligonucleotide primers used in this study

\begin{tabular}{|ll|}
\hline Primer & \multicolumn{1}{c|}{ Nucleotide sequence $\left(\mathbf{5}^{\prime} \mathbf{- \mathbf { 3 } ^ { \prime } ) ^ { * }}\right.$} \\
\hline algD_ol2 & CGGATCCTAGAATCCCCGGACGATCAAAG \\
algD_il3 & TCTAGATTCGGCGAAGTCGGTAGTGC \\
algD_ir3 & TCTAGAACGCACCGATCATCCGCAAG \\
algD_or2 & CGGATCCTTCGGGACGACCACGTGTTG \\
algD_cl & TTGGTTTGGGTTATGTCGG \\
algD_cr & TTGGTCATGAAGCCCACC \\
algT_fwd & CGGATCCCTTAACGAGGAGTGTTCATG \\
algT_revT7 & TAATACGACTCACTATAGGGAGGACGGTACCAACAGGACACTG \\
algD_fwd & GCGTATCAGCATATTTGGTTTGGG \\
algD_revT7 & TAATACGACTCACTATAGGGAGGCGTTGCAGGTGTACTTGATCA \\
23SrRNA_fwd\#1 & ACGTGGACCAGCCCTTAAGTTGTATTG \\
23SrRNA_revT7\#1 & TAATACGACTCACTATAGGGAGGCCCCCATATTCAGACAAG \\
\hline
\end{tabular}

${ }^{*}$ Restriction sites incorporated into primers are underlined: GGATCC, BamHI; TCTAGA, XbaI. T7 RNA polymerase promoter sequences incorporated into primers are in italic type. 


\section{RESULTS}

\section{Generation and characterization of alginate biosynthesis mutants}

The AlgT-producing and alginate-synthesizing P. syringae pv. glycinea strain, PG4180.muc, was found to be impaired in its in vitro growth, but showed increased in planta epiphytic fitness and better symptom development compared to the AlgT- and alginate-negative strain, PG4180 (Schenk et al., 2006). To find out whether this phenotype is based on alginate biosynthesis or is mediated by the AlgT sigma factor, algD mutants were generated in PG4180.muc and PG4180 by gene deletion (Table 3 ). The generated $\operatorname{alg} D$ mutants PG4180.muc.alg (mutant of PG4180.muc) and PG4180.alg (mutant of PG4180) were verified by PCR analysis. The algT mutation in PG4180 is caused by a single base pair exchange at position 10 of the algT ORF (Schenk et al., 2006). Therefore, the algT genotype was confirmed for all derivatives by nucleotide sequencing.

Visual examination of the mucoidy of bacterial colonies grown on MG agar plates at 18 and $28{ }^{\circ} \mathrm{C}$ showed a clear pattern of alginate production according to the respective genotypes (Table 3). Quantification of alginate production on MG agar plates at $28{ }^{\circ} \mathrm{C}$ for $96 \mathrm{~h}$ showed that the $\operatorname{alg} D$ and/or algT mutants produced only negligible amounts of alginate [less than $2.5 \mu \mathrm{g}$ alginate $(\mathrm{mg} \text { protein })^{-1}$, approximating the detection limits of the assay (Table 3 ). In contrast, PG4180.muc produced large amounts of alginate $\left[105.6 \mu \mathrm{g}\right.$ alginate $\left.(\mathrm{mg} \text { protein })^{-1}\right]$.

\section{In vitro and in planta growth studies}

The influence of alginate synthesis and AlgT on in vitro and in planta growth was studied using the four derivatives, PG4180.muc, PG4180.muc.alg, PG4180 and PG4180.alg (Table 3).

For in vitro growth studies, bacteria were cultured in HSC medium at 18 and $28{ }^{\circ} \mathrm{C}$, where $28{ }^{\circ} \mathrm{C}$ represents the optimal growth temperature and $18{ }^{\circ} \mathrm{C}$ represents the temperature at which $P$. syringae pv. glycinea is most virulent on its host plant (Ullrich et al., 2000). Optical density of cultures was monitored continuously until the cultures entered the late stationary phase (Fig. 1). PG4180.muc and its algD mutant PG4180.muc.alg were both found to be impaired in their in vitro growth at 18 and $28{ }^{\circ} \mathrm{C}$ compared to $\mathrm{PG} 4180$ and its respective $\operatorname{algD}$ mutant, PG4180.alg. This became most apparent in their extended doubling times $\left(t_{\mathrm{d}}\right)$ (1.2- to 1.4 -fold at 18 and $28{ }^{\circ} \mathrm{C}$, respectively) for PG4180.muc $\left(t_{\mathrm{d}} 18{ }^{\circ} \mathrm{C}: 9.3 \mathrm{~h} ; t_{\mathrm{d}}\right.$ $\left.28{ }^{\circ} \mathrm{C}: 6.3 \mathrm{~h}\right)$ compared to PG4180 $\left(t_{\mathrm{d}} 18{ }^{\circ} \mathrm{C}: 7.8 \mathrm{~h} ; t_{\mathrm{d}} 28^{\circ} \mathrm{C}\right.$ : $4.3 \mathrm{~h}$ ). Doubling times of the $\operatorname{alg} D$ mutants showed no significant differences to those of the corresponding parental strains, suggesting that the presence or absence of AlgT were the determining factors for these growth phenotypes.

Virulence, survival and in planta growth was evaluated by monitoring development of symptoms and bacterial populations on soybean plants for 28 days (Fig. 2). Plants were spray-inoculated with bacterial suspensions of $1 \times 10^{7}$ c.f.u. $\mathrm{ml}^{-1}$ as determined by living cell counts (data not shown). PG4180.muc and its algD mutant PG4180.muc.alg showed 10- to 20 -fold better survival $2 \mathrm{~h}$ after spraying compared to PG4180 and its respective $\operatorname{alg} D$ mutant, PG4180.alg. To rule out potential biases associated with the spray inoculation technique, the same bacterial suspensions were also sprayed into sterile glass flasks and their c.f.u. $\mathrm{ml}^{-1}$ values were determined before and after spraying. We found that spraying had no effect on the c.f.u. $\mathrm{ml}^{-1}$ values obtained (data not shown). One day post-inoculation, the c.f.u. $\mathrm{ml}^{-1}$ value dropped for all strains by about 50 - to 100 -fold. Bacterial populations started to increase in numbers from day 2 onwards (Fig. 2). Multiplication rates were about the same for all strains until day 7. From day 7 on, PG4180.muc and PG4180.muc.alg continued to grow to $1 \times 10^{8}$ c.f.u. $\mathrm{ml}^{-1}$, whereas PG4180 and its algD mutant remained at a 100 -fold lower stationary phase level with $1 \times 10^{6}$ c.f.u. $\mathrm{ml}^{-1}$. Both $\operatorname{alg} D$ mutants, particularly PG4180.muc.alg, showed slightly lower c.f.u. $\mathrm{ml}^{-1}$ values compared to their parental strains, and this decrease in population size was faster at the end of the sampling period. Symptom development was visually monitored 10-12 days post-infection. Although all infected plants showed symptoms characterized by necrotic lesions surrounded by chlorotic haloes, those plants infected with PG4180.muc and PG4180.muc.alg exhibited significantly more abundant symptoms than those treated with PG4180 or its algD mutant (data not shown).

PG4180.muc and PG4180.muc.alg, both possessing an intact $\operatorname{alg} T$ gene, had a clear advantage in their ability to survive and to increase population size on soybean leaves compared to PG4180 or its respective algD mutant,

Table 3. $P$. syringae pv. glycinea genotypes and resulting phenotypes

\begin{tabular}{|c|c|c|c|c|}
\hline \multirow[t]{2}{*}{ Strain } & \multicolumn{2}{|c|}{ Genotype } & \multirow{2}{*}{$\begin{array}{c}\text { Phenotype } \\
\text { Alginate }\end{array}$} & \multirow[t]{2}{*}{$\mu \mathrm{g}$ alginate $(\mu \mathrm{g} \text { protein })^{-1}$} \\
\hline & algT & algD & & \\
\hline PG4180.muc & + & + & + & $105.6 \pm 11.7$ \\
\hline PG4180.muc.alg & + & - & - & $1.6 \pm 1.5$ \\
\hline PG4180 & - & + & - & $2.1 \pm 0.6$ \\
\hline PG4180.alg & - & - & - & $1.0 \pm 0.5$ \\
\hline
\end{tabular}



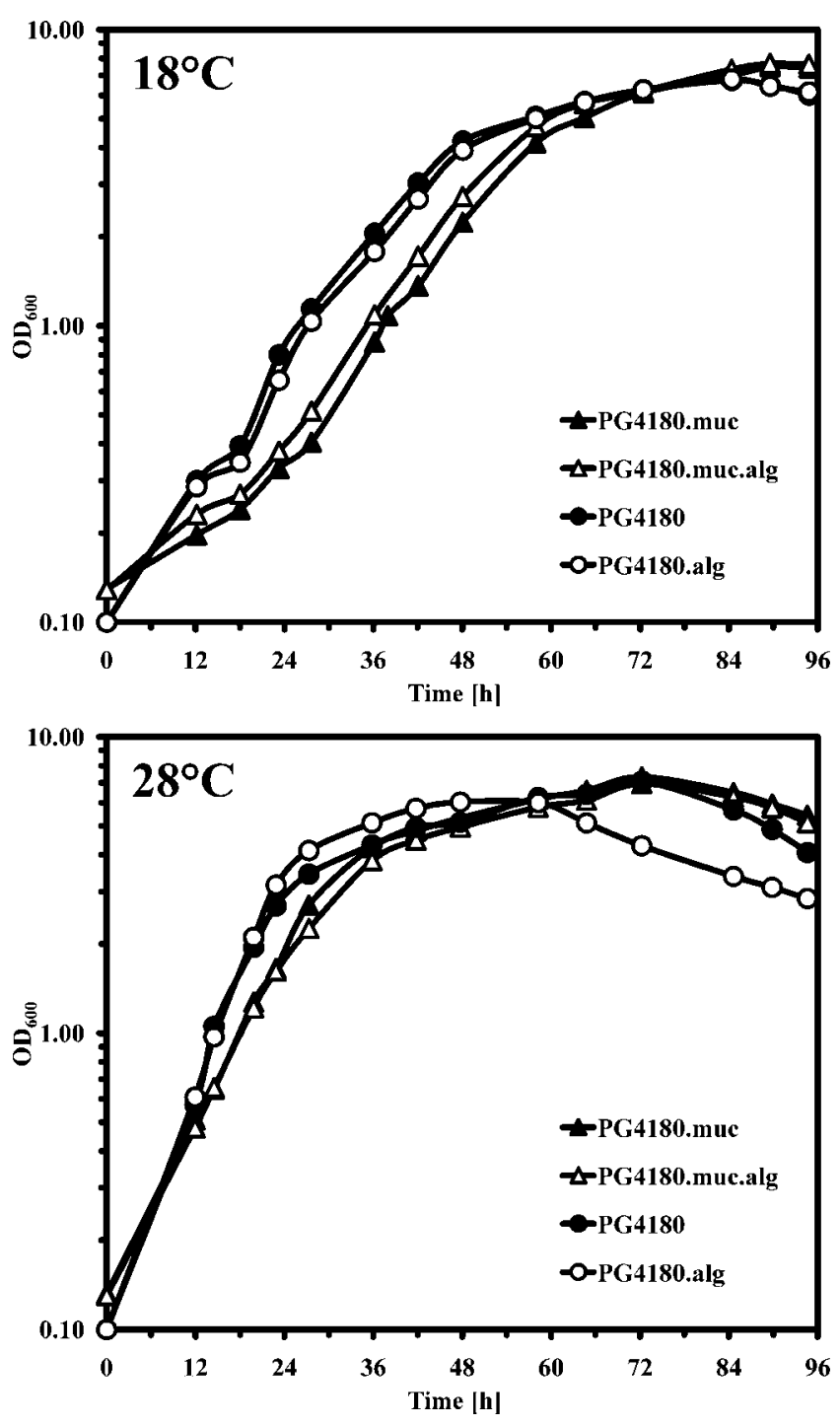

Fig. 1. In vitro growth of $P$. syringae PG4180.muc and PG4180.muc.alg (a), and PG4180 and PG4180.alg (b) in HSC medium at 18 and $28{ }^{\circ} \mathrm{C}$ as monitored by $\mathrm{OD}_{600}$. The data represent the mean values from six independent cultures per strain $(P<0.001)$.

PG4180.alg. The actual in planta multiplication rates during exponential growth showed no significant difference between all tested derivatives.

In summary, our results indicated that the presence of a functional AlgT, but not of alginate biosynthesis, hinders the ability to grow in vitro. In contrast, AlgT, but not alginate production, strongly promotes in planta survival and symptom development of $P$. syringae pv. glycinea.

\section{Analysis of algT and algD transcript levels in vitro and in planta}

Keith et al. (2003) indicated that algD transcription in $P$. syringae pv. tomato can be induced by plant-borne signals.

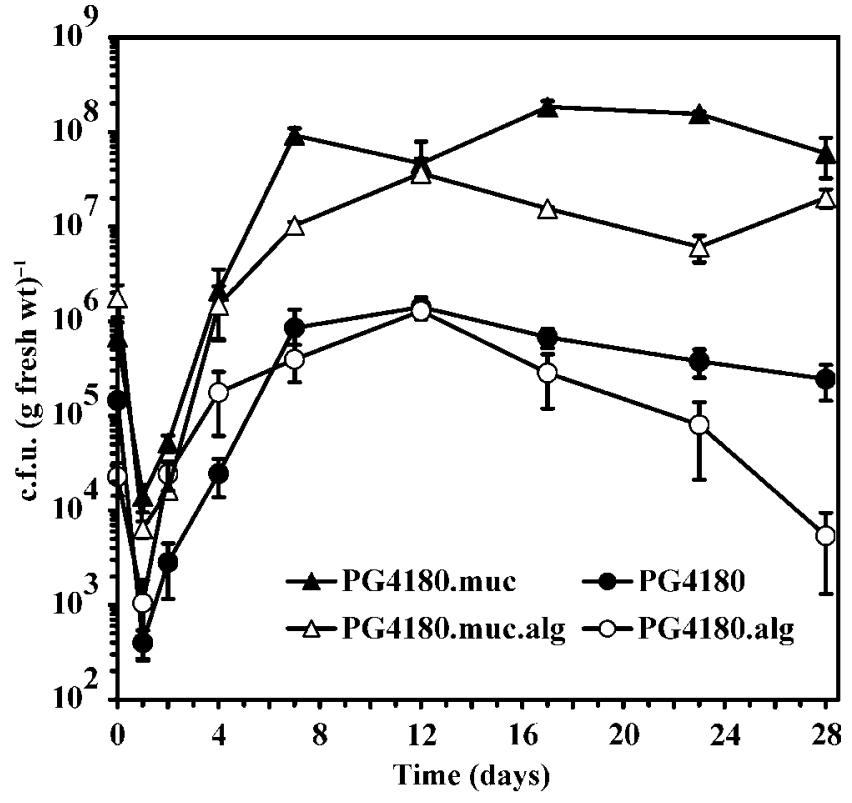

Fig. 2. In planta growth of $P$. syringae PG4180.muc and PG4180.muc.alg, and PG4180 and PG4180.alg on soybean leaves. Bacterial strains were spray-inoculated and plants were grown in shelves equipped with fluorescent lamps at $22-25{ }^{\circ} \mathrm{C}$. The data represent the mean values from three independent leaf samples. Error bars represent the SD from the means $(n=3$, $P<0.005)$.

To explore the situation in P. syringae pv. glycinea, in vitro and in planta transcript levels of algT and $\operatorname{alg} D$ at 18 and $28{ }^{\circ} \mathrm{C}$ in the alginate-producing strain PG4180.muc and its AlgT-negative counterpart, PG4180, were analysed by multiplexed spot blot Northern hybridization (Schenk et al., 2008) (Fig. 3).

For in vitro samples, PG4180.muc and PG4180 were cultured in $\mathrm{HSC}$ medium at 18 and $28{ }^{\circ} \mathrm{C}$ to an $\mathrm{OD}_{600}$ of 1.0. In planta samples were obtained by infiltration of soybean leaves with bacterial suspensions of $1 \times 10^{7}$ c.f.u. $\mathrm{ml}^{-1}$ followed by 3 days incubation in growth chambers at 18 or $28{ }^{\circ} \mathrm{C}$, as described previously (Schenk et al., 2006). DIG-labelled $\operatorname{algT}$ and algD probes were each multiplexed with an Oyster-645-labelled 23S\#1 probe and used for quantitative spot blot hybridizations with in vitro and in planta total RNA samples. All probes gave specific signals to samples containing $P$. syringae total RNA, but not to the plant total RNA controls (data not shown). Hybridization signals for algT and $\operatorname{alg} D$ were quantified and normalized with their corresponding $23 \mathrm{~S}$ rRNA signals as described previously (Schenk et al., 2008). Transcript levels for algT were 5- to 10-fold higher in all samples of strain PG4180.muc compared to PG4180 (Fig. 3). In planta data showed clear temperaturedependent and plant-inducible algT expression with highest values at $18{ }^{\circ} \mathrm{C}$, whereas in vitro transcription levels were twofold lower and not thermo-responsive. Expression 


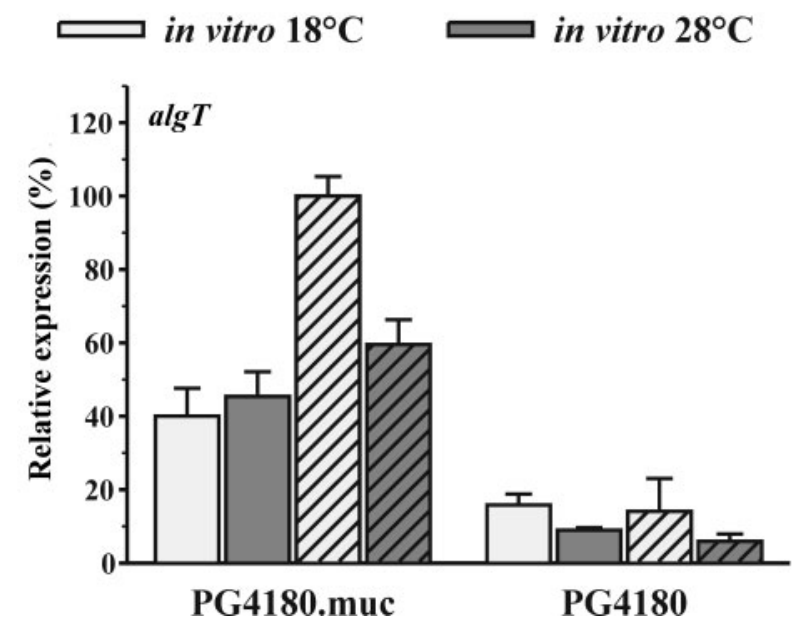

in planta $18^{\circ} \mathrm{C} \quad 0$ in planta $28^{\circ} \mathrm{C}$

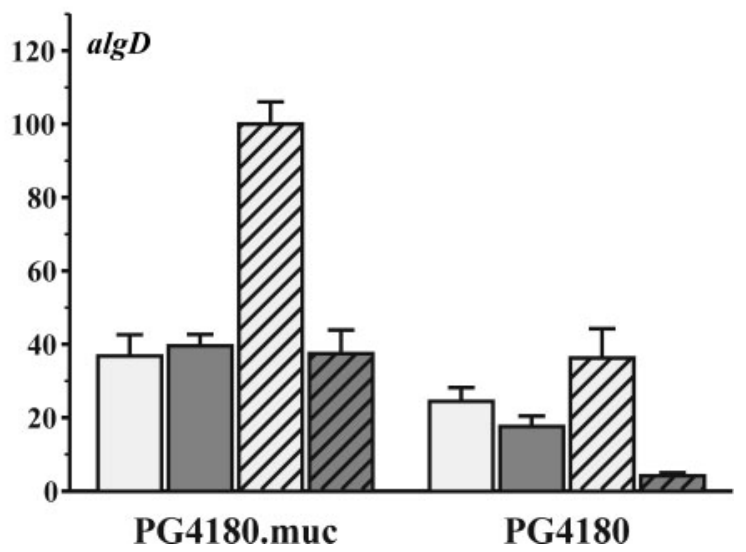

Fig. 3. Quantitative in vitro and in planta $\operatorname{alg} T$ and $a / g D$ gene expression. Relative abundance of $P$. syringae pv. glycinea alg $T$ and algD mRNA in vitro $\left(\mathrm{OD}_{600}\right.$ of 1.0 in HSC medium) and in planta (3 days after infiltration of soybean leaves with $1 \times 10^{7}$ c.f.u. $\mathrm{ml}^{-1}$ ) at 18 and $28^{\circ} \mathrm{C}$. Data was generated by multiplexed spot blot hybridization, quantification of gene-specific signals and normalization to the corresponding 23S rRNA signals. Error bars represent the SD from the means of replica spots $(n=3, P<0.001)$.

patterns of $\operatorname{alg} D$ resembled that of algT with the same temperature-dependent and plant-inducible phenotype. Transcript levels for $\operatorname{alg} D$ were 3- to 10-fold higher for PG4180.muc than for PG4180. Interestingly, the algT and algD transcript levels in PG4180 were not totally suppressed, suggesting a certain AlgT-independent background expression for both genes.

These data indicated that $\operatorname{alg} T$ as well as $\operatorname{alg} D$ were induced in planta in a temperature-dependent manner with higher expression at $18{ }^{\circ} \mathrm{C}$. Furthermore, our findings suggested that alginate biosynthesis in $P$. syringae pv. glycinea is transcriptionally activated by AlgT both in vitro and in planta.

\section{DISCUSSION}

In this study, the role of the EPS alginate and the sigma factor AlgT in the soybean plant pathogen $P$. syringae pv. glycinea PG4180 was investigated. To identify potential temperature-mediated or plant-borne effects on gene expression of alginate biosynthesis and $\mathrm{AlgT}$, transcription was analysed in vitro and in planta at two temperatures, 18 and $28{ }^{\circ} \mathrm{C}$.

In a previous study, lack of alginate production in PG4180 was found to be caused by a nonsense mutation in algT (Schenk et al., 2006). This mutation reverted in the PG4180.muc derivative into an intact ORF and led to expression of a functional $\mathrm{Alg} \mathrm{T}$ protein. Interestingly, PG4180.muc was impaired in its in vitro growth, but showed increased epiphytic fitness in planta and significantly larger numbers of typical disease symptoms compared to the AlgT-deprived strain PG4180. This raised the question whether the observed phenotype was due to the ability to produce alginate or was based on other regulatory effects of AlgT. In the present study, generation of algD knockout mutants in PG4180.muc and PG4180 enabled us to dissect EPS synthesis effects from other potential effects of the alternative sigma factor AlgT.

The characterization of the two $\operatorname{alg} D$ mutants showed that disruption of $\operatorname{alg} D$ led to an alginate-negative phenotype as expected, since $\operatorname{alg} D$ had been shown to be indispensable for alginate biosynthesis in $P$. aeruginosa (Tatnell et al., 1994). We did not observe a significant difference in alginate production between the AlgT-deficient strain PG4180 and its algD mutant, PG4180.alg. This adds evidence to the model in which AlgT comprises the main activator and regulatory switch for alginate biosynthesis in $P$. syringae pv. glycinea in vitro. This had previously been demonstrated for the related phytopathogen $P$. syringae pv. syringae FF5 (Fakhr et al., 1999; Keith \& Bender, 1999) and the opportunistic human pathogen $P$. aeruginosa (Hershberger et al., 1995; Martin et al., 1994; Ohman et al., 1996).

Comparison of in vitro and in planta growth and virulence of the PG4180 derivatives analysed (Table 3) demonstrated an impaired in vitro growth, an increased in planta epiphytic fitness and a significantly larger number of symptoms for PG4180.muc compared to PG4180, which confirmed our previous data (Schenk et al., 2006). The algD mutants PG4180.muc.alg and PG4180.alg showed identical in vitro and very similar in planta phenotypes compared to their respective parental strains. This surprising result led to the conclusion that AlgT is mainly responsible for impaired in vitro growth and increased in planta epiphytic fitness in strain PG4180.muc. If alginate 
biosynthesis had caused this phenotype, the $\operatorname{alg} D$ mutant PG4180.muc.alg should have exhibited a phenotype different from that of its parental strain PG4180.muc, but rather similar to that of PG4180 or PG4180.alg. In contrast to our findings, a different in planta scenario had been previously described for an $\operatorname{alg} L^{-}$alginate mutant in the related phytopathogen $P$. syringae pv. syringae FF5 (Yu et al., 1999). A slightly lower in planta population size for PG4180.muc.alg in comparison to PG4180.muc could be assigned to lack of alginate biosynthesis and was also found in PG4180.alg, compared to its parental strains. This result demonstrated that $P$. syringae AlgT has a significant impact on in planta growth and virulence while alginate production only seems to be of marginal importance. This contradicts results of some other studies where alginate production had been associated with epiphytic fitness, virulence and symptom development (Fett \& Dunn, 1989; Gross \& Rudolph, 1987b; Osman et al., 1986; Rudolph et al., 1994; Yu et al., 1999). However, in support of our findings, Beattie \& Lindow (1994) identified P. syringae mutants that were EPS-deficient in culture but were indistinguishable from their parental strain with respect to their epiphytic growth and survival. Likewise, a screen of Tn5 mutants of the closely related phytopathogen $P$. syringae pv. syringae B728a revealed several EPS-altered mutants which were only slightly or not altered in growth or survival on bean leaves (Lindow et al., 1993).

It remains unknown which genes, besides those involved in alginate biosynthesis, are controlled by AlgT in $P$. syringae. In $P$. aeruginosa it was shown that AlgT directs transcription of a large set of virulence determinants or toxic factors (Firoved et al., 2002; Firoved \& Deretic, 2003) and of the gene encoding the main heat-shock factor RpoH (Schurr \& Deretic, 1997). Microarray analysis revealed that AlgT exerts broad-range regulatory effects on approximately $6 \%$ of the $P$. aeruginosa genome, with alginate and flagellar genes accounting for only one-fifth of AlgT-regulated genes (Tart et al., 2005). AlgT was found to be essential for the tolerance of a $P$. fluorescens biocontrol strain towards desiccation and osmotic stress (Schnider-Keel et al., 2001). A $P$. syringae pv. syringae algT mutant displayed increased sensitivity to heat, paraquat and hydrogen peroxide, and algT expression could be stimulated by heat shock, osmotic and oxidative stress (Keith \& Bender, 1999). Therefore, we propose a role for $\operatorname{AlgT}$ as a transcriptional regulator of several yet-to-be determined genetic traits important for in planta growth, survival and virulence of $P$. syringae.

Not surprisingly, transcript levels were elevated for $\operatorname{alg} T$ and $a l g D$ in PG4180.muc compared to PG4180. It is known that AlgT auto-induces transcription of the algT-muc gene cluster and that of the alginate biosynthetic operon in $P$. aeruginosa (Govan \& Deretic, 1996; Schenk et al., 2006). In vitro, no temperature-dependent transcription was observed, but in planta expression of algT and $\operatorname{alg} D$ was clearly induced at the lower temperature of $18{ }^{\circ} \mathrm{C}$, indicating that plant-borne signals combined with low temperature activate $\operatorname{alg} T$ and, in consequence, $\operatorname{alg} D$ transcription as well. Although at a lower level, algD transcription in PG4180 showed a thermoresponsive and plant-inducible pattern comparable to that in PG4180.muc, indicating that additional yet unknown factors influence $\operatorname{alg} D$ transcription besides AlgT.

In conclusion, the sigma factor AlgT contributes to $P$. syringae pv. glycinea in planta growth, survival and symptom development, whereas in vitro bacterial growth is negatively influenced by AlgT. Simultaneously, our observations indicated a negligible role for the EPS alginate for in planta growth and virulence. Future studies will focus on the identification of unknown AlgT-dependent genes in $P$. syringae and may thus help to reveal a potential AlgT regulon, which in turn might include novel plant-inducible genes or those important for the plant-microbe interaction.

\section{ACKNOWLEDGEMENTS}

The authors wish to thank C. L. Bender, A. Wensing, Y. Braun, M. Lindemann, M. Winterhalter and U. Schwaneberg for stimulating discussions, critical comments and support. This work was supported by grants of the Max-Planck Society and the Deutsche Forschungsgemeinschaft.

\section{REFERENCES}

Alfano, J. R. \& Collmer, A. (1996). Bacterial pathogens in plants: life up against the wall. Plant Cell 8, 1683-1698.

Anastassiou, E. D., Mintzas, A. C., Kounavis, C. \& Dimitracopoulos, G. (1987). Alginate production by clinical nonmucoid Pseudomonas aeruginosa strains. J Clin Microbiol 25, 656-659.

Ausubel, F., Brent, R., Kingston, R. E., Moore, D. D., Seidman, J. G., Smith, J. A. \& Struhl, K. (1994). Current Protocols in Molecular Biology. New York: Wiley.

Beattie, G. A. \& Lindow, S. E. (1994). Epiphytic fitness of phytopathogenic bacteria: physiological adaptations for growth and survival. Curr Top Microbiol Immunol 192, 1-27.

Chitnis, C. E. \& Ohman, D. E. (1993). Genetic analysis of the alginate biosynthetic gene cluster of Pseudomonas aeruginosa shows evidence of an operonic structure. Mol Microbiol 8, 583-593.

Denny, T. P. (1995). Involvement of bacterial polysaccharides in plant pathogenesis. Annu Rev Phytopathol 33, 173-197.

Fakhr, M. K., Peñaloza-Vázquez, A., Chakrabarty, A. M. \& Bender, C. L. (1999). Regulation of alginate biosynthesis in Pseudomonas syringae pv. syringae. J Bacteriol 181, 3478-3485.

Fett, W. F. \& Dunn, M. F. (1989). Exopolysaccharides produced by phytopathogenic Pseudomonas syringae pathovars in infected leaves of susceptible hosts. Plant Physiol 89, 5-9.

Fett, W. F., Wijey, C. \& Lifson, E. R. (1992). Occurrence of alginate gene sequences among members of the pseudomonad rRNA homology groups I-IV. FEMS Microbiol Lett 78, 151-157.

Fialho, A. M., Zielinski, N. A., Fett, W. F., Chakrabarty, A. M. \& Berry, A. (1990). Distribution of alginate gene sequences in the Pseudomonas rRNA homology group I-Azomonas-Azotobacter lineage of superfamily B procaryotes. Appl Environ Microbiol 56, 436-443.

Figurski, D. H. \& Helinski, D. R. (1979). Replication of an origincontaining derivative of plasmid RK2 dependent on a plasmid function provided in trans. Proc Natl Acad Sci U S A 76, 1648-1652. 
Firoved, A. M. \& Deretic, V. (2003). Microarray analysis of global gene expression in mucoid Pseudomonas aeruginosa. J Bacteriol 185, 1071-1081.

Firoved, A. M., Boucher, J. C. \& Deretic, V. (2002). Global genomic analysis of $\operatorname{AlgU}\left(\sigma^{\mathrm{E}}\right)$-dependent promoters (sigmulon) in Pseudomonas aeruginosa and implications for inflammatory processes in cystic fibrosis. J Bacteriol 184, 1057-1064.

Govan, J. R. \& Deretic, V. (1996). Microbial pathogenesis in cystic fibrosis: mucoid Pseudomonas aeruginosa and Burkholderia cepacia. Microbiol Rev 60, 539-574.

Gross, M. \& Rudolph, K. (1987a). Studies on the extracellular polysaccharides (EPS) produced in vitro by Pseudomonas phaseolicola. I. Indications for a polysaccharide resembling alginic acid in seven $P$. syringae pathovars. J Phytopathol 118, 276-287.

Gross, M. \& Rudolph, K. (1987b). Studies on the extracellular polysaccharides (EPS) produced in vitro by Pseudomonas phaseolicola. II. Characterization of levan, alginate, and LPS. J Phytopathol 119, 206-215.

Hershberger, C. D., Ye, R. W., Parsek, M. R., Xie, Z. D. \& Chakrabarty, A. M. (1995). The algT (algU) gene of Pseudomonas aeruginosa, a key regulator involved in alginate biosynthesis, encodes an alternative $\sigma$ factor $\left(\sigma^{\mathrm{E}}\right)$. Proc Natl Acad Sci U S A 92, 7941-7945.

Hettwer, U., Jaeckel, F. R., Boch, J., Meyer, M., Rudolph, K. \& Ullrich, M. S. (1998). Cloning, nucleotide sequence, and expression in Escherichia coli of levansucrase genes from the plant pathogens Pseudomonas syringae pv. glycinea and P. syringae pv. phaseolicola. Appl Environ Microbiol 64, 3180-3187.

Hirano, S. S. \& Upper, C. D. (2000). Bacteria in the leaf ecosystem with emphasis on Pseudomonas syringae - a pathogen, ice nucleus, and epiphyte. Microbiol Mol Biol Rev 64, 624-653.

Hoang, T. T., Karkhoff-Schweizer, R. R., Kutchma, A. J. \& Schweizer, H. P. (1998). A broad-host-range Flp-FRT recombination system for site-specific excision of chromosomally-located DNA sequences: application for isolation of unmarked Pseudomonas aeruginosa mutants. Gene 212, 77-86.

Kado, C. I. \& Liu, S. T. (1981). Rapid procedure for detection and isolation of large and small plasmids. J Bacteriol 145, 1365-1373.

Keane, P. J., Kerr, A. \& New, P. B. (1970). Crown gall of stone fruit. II. Identification and nomenclature of Agrobacterium isolates. Aust J Biol Sci 23, 585-595.

Keith, L. M. W. \& Bender, C. L. (1999). AlgT $\left(\sigma^{22}\right)$ controls alginate production and tolerance to environmental stress in Pseudomonas syringae. J Bacteriol 181, 7176-7184.

Keith, R. C., Keith, L. M. W., Hernández-Guzmán, G., Uppalapati, S. R. \& Bender, C. L. (2003). Alginate gene expression by Pseudomonas syringae pv. tomato DC3000 in host and non-host plants. Microbiology 149, 1127-1138.

Kidambi, S. P., Sundin, G. W., Palmer, D. A., Chakrabarty, A. M. \& Bender, C. L. (1995). Copper as a signal for alginate synthesis in Pseudomonas syringae pv. syringae. Appl Environ Microbiol 61, 2172-2179.

Lam, J., Chan, R., Lam, K. \& Costerton, J. W. (1980). Production of mucoid microcolonies by Pseudomonas aeruginosa within infected lungs in cystic fibrosis. Infect Immun 28, 546-556.

Lindow, S. E., Andersen, G. \& Beattie, G. A. (1993). Characteristics of insertional mutants of Pseudomonas syringae with reduced epiphytic fitness. Appl Environ Microbiol 59, 1593-1601.

Martin, D. W., Schurr, M. J., Yu, H. \& Deretic, V. (1994). Analysis of promoters controlled by the putative sigma factor AlgU regulating conversion to mucoidy in Pseudomonas aeruginosa: relationship to sigma E and stress response. J Bacteriol 176, 6688-6696.

Mathee, K., Kharazami, A. A. \& Høiby, N. (2002). Role of exopolysaccharide in biofilm matrix formation: the alginate paradigm. In Molecular Ecology of Biofilms, pp. 23-55. Edited by R. J. C. McLean. Norfolk: Horizon.

May, T. B. \& Chakrabarty, A. M. (1994). Isolation and assay of Pseudomonas aeruginosa alginate. Methods Enzymol 235, 295-304.

Ohman, D. E., Marhee, K., McPherson, C. J., DeVries, C. A., Ma, S., Wozniak, D. J. \& Franklin, M. J. (1996). Regulation of the alginate $(\operatorname{algD})$ operon in Pseudomonas aeruginosa. In Molecular Biology of Pseudomonads, pp. 472-483. Edited by T. Nakazawa, K. Furukawa, D. Haas \& S. Silver. Washington, DC: American Society for Microbiology.

Osman, S. F., Fett, W. F. \& Fishman, M. L. (1986). Exopolysaccharides of the phytopathogen Pseudomonas syringae pv. glycinea. J Bacteriol 166, 66-71.

Palmer, D. A. \& Bender, C. L. (1993). Effects of environmental and nutritional factors on production of the polyketide phytotoxin coronatine by Pseudomonas syringae pv. glycinea. Appl Environ Microbiol 59, 1619-1623.

Peñaloza-Vázquez, A., Kidambi, S. P., Chakrabarty, A. M. \& Bender, C. L. (1997). Characterization of the alginate biosynthetic gene cluster in Pseudomonas syringae pv. syringae. J Bacteriol 179, 4464-4472.

Peñaloza-Vázquez, A., Fakhr, M. K., Bailey, A. M. \& Bender, C. L. (2004). AlgR functions in algC expression and virulence in Pseudomonas syringae pv. syringae. Microbiology 150, 2727-2737.

Pier, G. B. (1998). Pseudomonas aeruginosa: a key problem in cystic fibrosis. ASM News 64, 339-347.

Pier, G. B., Desjardins, D., Aguilar, T., Barnard, M. \& Speert, D. P. (1986). Polysaccharide surface antigens expressed by nonmucoid isolates of Pseudomonas aeruginosa from cystic fibrosis patients. J Clin Microbiol 24, 189-196.

Rudolph, K. W. E., Groß, M., Ebrahim-Nesbat, F., Nöllenburg, M., Zomorodian, A., Wydra, K., Neugebauer, M., Hettwer, U., El-Shouny, W. \& other authors (1994). The role of extracellular polysaccharides as virulence factors for phytopathogenic pseudomonads and xanthomonads. In Molecular Mechanisms for Bacterial Virulence, pp. 357378. Edited by C. I. Kado \& J. H. Cross. Dordrecht: Kluwer.

Sambrook, J., Fritsch, E. F. \& Maniatis, T. (1989). Molecular Cloning: a Laboratory Manual, 2nd edn. Cold Spring Harbor, NY: Cold Spring Harbor Laboratory.

Schenk, A., Berger, M., Keith, L. M., Bender, C. L., Muskhelishvili, G. \& Ullrich, M. S. (2006). The algT gene of Pseudomonas syringae pv. glycinea and new insights into the transcriptional organization of the algT-muc gene cluster. J Bacteriol 188, 8013-8021.

Schenk, A., Weingart, H. \& Ullrich, M. S. (2008). Extraction of high quality bacterial and plant total RNA from infected leaf tissue for bacterial in planta gene expression analysis by multiplexed fluorescent Northern hybridization. Mol Plant Pathol (in press).

Schnider-Keel, U., Lejbølle, K. B., Baehler, E., Haas, D. \& Keel, C. (2001). The sigma factor AlgU (AlgT) controls exopolysaccharide production and tolerance towards desiccation and osmotic stress in the biocontrol agent Pseudomonas fluorescens CHA0. Appl Environ Microbiol 67, 5683-5693.

Schurr, M. J. \& Deretic, V. (1997). Microbial pathogenesis in cystic fibrosis - co-ordinate regulation of heat-shock response and conversion to mucoidy in Pseudomonas aeruginosa. Mol Microbiol 24, 411-420.

Smirnova, A., Li, H., Weingart, H., Aufhammer, S., Burse, A., Finis, K., Schenk, A. \& Ullrich, M. S. (2001). Thermoregulated expression of virulence factors in plant-associated bacteria. Arch Microbiol 176, 393-399.

Tart, A. H., Wolfgang, M. C. \& Wozniak, D. J. (2005). The alternative sigma factor AlgT represses Pseudomonas aeruginosa flagellum biosynthesis by inhibiting expression of fleQ. J Bacteriol 187, 7955-7962. 
Tatnell, P. J., Russell, N. J. \& Gacesa, P. (1994). GDP-mannose dehydrogenase is the key regulatory enzyme in alginate biosynthesis in Pseudomonas aeruginosa: evidence from metabolite studies. Microbiology 140, 1745-1754.

Ullrich, M. S., Schergaut, M., Boch, J. \& Ullrich, B. (2000). Temperature-responsive genetic loci in the plant pathogen Pseudomonas syringae pv. glycinea. Microbiology 146, 2457-2468.

Whitfield, C. (1988). Bacterial extracellular polysaccharides. Can J Microbiol 34, 415-420.
Yu, J., Peñaloza-Vázquez, A., Chakrabarty, A. M. \& Bender, C. L. (1999). Involvement of the exopolysaccharide alginate in the virulence and epiphytic fitness of Pseudomonas syringae pv. syringae. Mol Microbiol 33, 712-720.

Zielinski, N. A., Chakrabarty, A. M. \& Berry, A. (1991). Characterization and regulation of the Pseudomonas aeruginosa algC gene encoding phosphomannomutase. J Biol Chem 266, 9754-9763.

Edited by: P. Cornelis 